\title{
The effect of clay particles on the efficacy of a biocide
}

\section{M.O. Pereira, M.J. Vieira, L.F. Melo}

Centro de Engenharia Biológica-IBQF, Universidade do Minho, 4700-057 Braga, Portugal

Abstract The effect of kaolin particles on the bacterial activity as well as on the efficacy of a biocide was investigated. The results show that the presence of the clay particles enhance the Pseudomonas fluorescens activity for all buffered $\mathrm{pH}$ values tested, this increase being more relevant for the more adverse $\mathrm{pH}$ for this bacteria growth. The results also demonstrated that kaolin reduces the ability of desinfection of a carbamatebased biocide against $P$. fluorescens suspensions.

Keywords Biocide; biofilm; clay particles; Pseudomonas fluorescens; respiratory activity

\section{Introduction}

Process water obtained from rivers and lakes usually contains microbial cells, sand, silt and clays, among other inorganic components. The presence of clay minerals is particularly important since they can attract substrates and retain water molecules (Burns, 1989) due to their large surface area and specific surface charge. When clays are introduced in water solutions, they can affect microbial metabolism, by changing the physico-chemical properties of the surrounding environment (indirect effects), or through surface interactions (direct effects) with the living cells (Stotzky, 1986).

Kaolinite is a common clay mineral, mainly composed by aluminum silicates, which occurs in the form of thin, roughly hexagonal platelets. This mineral is stable because of its limited isomorphous substitution (it has a low cation exchange capacity) and generally nonexpanding lattices (Burns, 1989).

In the present study, the effect of small kaolin particles (basically containing kaolinite) in the efficacy of a biocide against bacterial suspensions of Pseudomonas fluorescens was investigated.

\section{Materials and methods}

Microorganism and Cell Growth: A continuous pure culture of the Gram-negative aerobic bacteria Pseudomonas fluorescens was grown in a $3 \mathrm{~L}$ glass fermenter, suitably aerated and magnetically agitated. The fermenter was continuously fed with a sterile nutrient solution consisting of $5 \mathrm{~g}$ glucose/L, $2.5 \mathrm{~g}$ peptone/L and $1.25 \mathrm{~g}$ yeast extract/L, in phosphate buffer $\mathrm{pH} 7$.

Biocide: A non-oxidising biocide solution composed of sodium dimethyl dithiocarbamate $(15 \% \mathrm{w} / \mathrm{v})$ and disodium ethylene bisothiocarbamate $(15 \% \mathrm{w} / \mathrm{v})$ in water was tested.

Clay particles: Kaolin particles (BA220C) with diameters between 5 and 10 microns were used to investigate the effect of abiotic particles on the respiratory activity of suspended cultures of the bacteria referred to above. In all experiments, the effective concentration of kaolin was $300 \mathrm{mg} / \mathrm{L}$.

Analytical Methods: Periodically, a suitable amount of P. fluorescens culture was removed from the fermenter, under sterilised conditions, centrifuged (5000 rpm, $10 \mathrm{~min}$ ) and washed three times with phosphate buffer. The pellets obtained were ressuspended in several buffers: phosphate buffer $\mathrm{pH} 7$ and $\mathrm{pH} 9$ and acetate buffer $\mathrm{pH}$ 5, according to the $\mathrm{pH}$ value 
wanted in each assay, and a known amount of kaolin (300 g/L) was added to this suspended culture.

The bacterial culture was then divided into several sterilised glass flasks and put in an orbital shaker $\left(120 \mathrm{rpm}, 27^{\circ} \mathrm{C}\right)$. After $30 \mathrm{~min}$ (the time needed to ensure a suitable adaptation of the bacteria to the new $\mathrm{pH}$ established), a known amount of biocide was added to each flask in order to obtain different concentrations of the chemical $(100,200$ and $300 \mathrm{mg} / \mathrm{L}$ ). One of the flasks was used as a control, without biocide addition. At known time intervals (immediately after the addition, 1,3 and $7 \mathrm{~h}$ ), a sample of each flask was transferred into a respiration chamber to evaluate their cellular activity (through oxygen consumption).

Oxygen Uptake Rates Measurement: The respiratory activity of the several samples was evaluated by measuring oxygen uptake rates in a biological oxygen monitor (BOM) in short-term assays. The assays were performed in a Yellow Springs Instruments BOM (Model 53) and the procedure used was described elsewhere (Nogueira et al., 1998).

\section{Results}

As can be seen on Table I, the microbial activity was stimulated by the presence of the kaolin particles for all $\mathrm{pH}$ values studied, the major increase being obtained with $\mathrm{pH} 5$. In the case of the $\mathrm{pH} 7$ (the optimum $\mathrm{pH}$ for growth of P. fluorescens) the effect was rather small, indicating that the kaolin effect is more expressive when the growth conditions deviate from the optimum values.

Table I Increase in bacterial activity caused by the presence of kaolin particles, at several $\mathrm{pH}$ values, as a function of time

\begin{tabular}{llll}
\hline & \multicolumn{3}{l}{ Bacterial Activity } \\
\cline { 2 - 4 } $\begin{array}{l}\text { Time } \\
\text { (h) }\end{array}$ & $\mathbf{p H ~ 7}$ & $\mathbf{p H} 9$ & $\mathbf{p H ~ 5}$ \\
\hline 0 & 10.9 & 19.1 & 28.6 \\
1 & - & 36.4 & 27.0 \\
3 & 12.5 & 37.3 & 43.1 \\
7 & 11.2 & 38.8 & 33.6 \\
\hline
\end{tabular}

Table II $\mathrm{pH}$ values obtained in the assays with suspended cultures containing $300 \mathrm{mg} / \mathrm{L}$ of kaolin, as a function of time (for different initial $\mathrm{pH}$ in buffered medium)

\begin{tabular}{llll}
\hline & \multicolumn{3}{c}{ pH measured after kaolin addition } \\
\cline { 2 - 4 } $\begin{array}{l}\text { Time } \\
\text { (h) }\end{array}$ & Initial pH 5 & Initial pH 7 & Initial pH 9 \\
\hline 0 & 5.10 & 7.00 & 9.10 \\
1 & 5.04 & 6.96 & 9.08 \\
3 & 5.05 & 6.99 & 9.07 \\
7 & 5.05 & 6.98 & 8.93 \\
24 & 5.05 & 6.98 & 8.89 \\
\hline
\end{tabular}

Stotzky (1986) and Burns (1989) stated that addition of clay particles improves microbial activity because they are able to maintain the $\mathrm{pH}$ within suitable values. In order to verify whether the $\mathrm{pH}$ of each buffered assay was modified by the presence of $300 \mathrm{mg} / \mathrm{L}$ of kaolin, the $\mathrm{pH}$ of the suspended cultures was monitored, as a function of time. Table II summarises the results obtained.

As can be seen on Table II, no relevant change was obtained. The maintenance of the $\mathrm{pH}$ of the media around the buffered values, as a consequence of the strength of the buffer, indicates that, the effect of kaolin as $\mathrm{pH}$ regulator does not exist in buffered solutions.

Respirometric experiments were carried out in order to study the effect of kaolin particles on the efficacy of the carbamate-based biocide. The results for the case of $\mathrm{pH} 7$ are shown in Figure 1.

The presence of different concentrations of the carbamate-based biocide causes, in general, a reduction in the activity of the $P$. fluorescens both with or without the presence of kaolin particles (cf Figure 1a and 1b). There are, however, some significant differences. In the assays carried out with kaolin, the reduction in the bacterial activity caused by carbamate, is smaller than in the assays without kaolin. This fact can be better observed on Table 

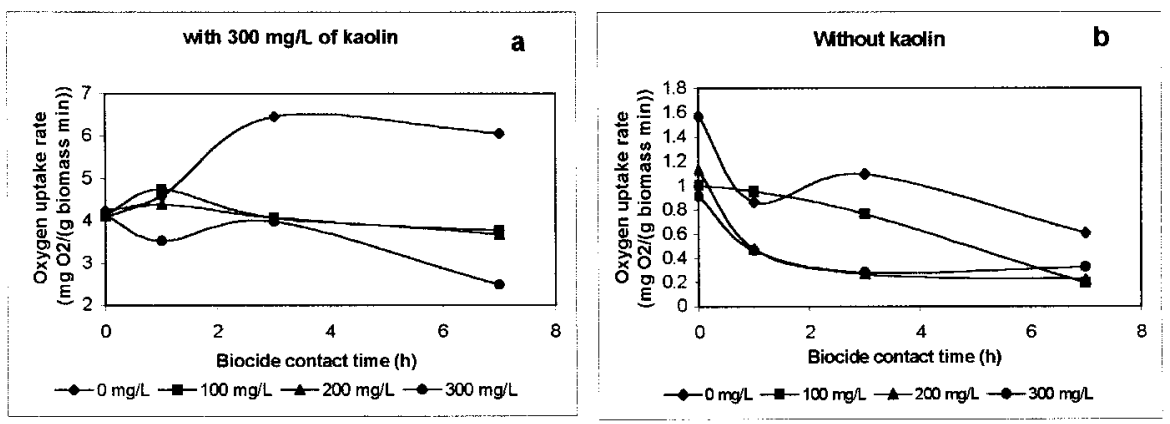

Figure 1 Oxygen uptake rates of suspended cultures of $P$. fluorescens, $\mathrm{pH} 7$ phosphate buffer, with (a) and without (b) $300 \mathrm{mg} / \mathrm{L}$ of kaolin, when treated with different concentrations of carbamate

Table III Reduction in the bacterial activity in the assays performed at $\mathrm{pH}$ 7, with and without kaolin, for different concentrations of carbamate, as a function of time

\begin{tabular}{|c|c|c|c|c|c|c|}
\hline \multirow{3}{*}{$\begin{array}{l}\text { Biocide } \\
\text { contact time } \\
\text { (h) }\end{array}$} & \multicolumn{6}{|c|}{ Bacterial Activity Reduction (\%) } \\
\hline & \multicolumn{3}{|c|}{ Without kaolin } & \multicolumn{3}{|c|}{ With $300 \mathrm{mg} / \mathrm{L}$ of kaolin } \\
\hline & $\begin{array}{l}100 \mathrm{mg} / \mathrm{L} \text { of } \\
\text { carbamate }\end{array}$ & $\begin{array}{l}200 \mathrm{mg} / \mathrm{L} \text { of } \\
\text { carbamate }\end{array}$ & $\begin{array}{c}300 \mathrm{mg} / \mathrm{L} \text { of } \\
\text { carbamate }\end{array}$ & $\begin{array}{l}100 \mathrm{mg} / \mathrm{L} \text { of } \\
\text { carbamate }\end{array}$ & $\begin{array}{l}200 \mathrm{mg} / \mathrm{L} \text { of } \\
\text { carbamate }\end{array}$ & $\begin{array}{l}300 \mathrm{mg} / \mathrm{L} \text { of } \\
\text { carbamate }\end{array}$ \\
\hline $0^{*}$ & 36.3 & 28.2 & 41.8 & 2.1 & 3.1 & 2.7 \\
\hline 1 & - & 45.0 & 46.3 & - & 4.5 & 23.3 \\
\hline 3 & 30.2 & 75.5 & 74.2 & 37.2 & 37.0 & 38.4 \\
\hline 7 & 68.3 & 63.3 & 46.0 & 38.0 & 39.3 & 59.1 \\
\hline
\end{tabular}

$\left({ }^{*}\right)$ immediately after biocide addition

III, that presents the differences (in percentage) between the activity values in the control assay (i.e. without biocide) and the ones obtained in the assays with biocide, for each time interval, and for both assay sets (i. e. with and without kaolin).

\section{Discussion}

The clay ability to adsorb the products of bacterial metabolism, maintaining a constant hydrogen ion concentration (Burns, 1989), and, therefore, a suitable $\mathrm{pH}$ for bacterial growth, is usually mentioned to explain the enhancement of cell activity. In the present study, the increase in the $P$. fluorescens activity cannot be argued in these terms, because the culture media used for bacteria cultivation were initially buffered at different fixed $\mathrm{pH}$ values. Moreover, these $\mathrm{pH}$ values did not change significantly with time (Table II), which means that kaolin does not act as a $\mathrm{pH}$ regulator in the present study. Therefore, the increase in bacterial activity must be attributed to other mechanisms than the maintenance of $\mathrm{pH}$.

According to Stotzky (1986), some clay species increase the respiration of most bacteria even when the culture media are initially adjusted to or buffered at $\mathrm{pH} 7$, indicating that some additional mechanism may be involved in the stimulation of the respiratory activity by clay minerals. Unfortunately, until this moment such additional mechanisms were not well defined, although some hypotheses have been suggested but not confirmed (Srinivasan et al., 1995). Also, there is not yet a sound explanation for the smaller effect of kaolin in the case of $\mathrm{pH} 7$, as compared to the assays at $\mathrm{pH} 5$ and 9.

The decrease obtained in the bacterial activity, when the microbial cultures were treated with carbamate (Figure 1) was expected. This decrease is due to the toxic activity of the biocide, although carbamate is known as a mild biocide. The low biocide efficacy in the assays 
with kaolin, when compared with that achieved without kaolin, (Table III) was, in a certain way, remarkable. According to Burns (1975), the adsorption of pesticides on clays influences their availability to microorganisms. Once adsorbed, pesticides could lose partially or totally their toxic activity. On the other hand, it is generally assumed that particleattached bacteria are less sensitive to biocides than the same bacteria in planktonic state (Nichols 1989). Therefore, the low biocide efficacy obtained in the assays performed with kaolin could be the result of the conjugation of the two following factors: the adsorption of carbamate to kaolin with the consequent reduction in its activity; and the effect of cell adhesion to kaolin particles that seems to protect them from adverse external conditions (toxic activity of the carbamate).

\section{Conclusions}

The present work indicates that the presence of kaolin: (a) stimulates the activity of $P$. fluorescens suspension for all $\mathrm{pH}$ values studied (5, 7 and 9), this effect being more evident for the assays performed at $\mathrm{pH} 5$ and 9; (b) decreases the efficiency of disinfection of the carbamate.

The use of biocides to reduce or eliminate microorganisms, mainly when they are entrapped in a biofilm, is widespread, therefore, the knowledge of the effect of clay particles on the efficacy of these biocides acquires increased importance.

\section{Acknowledgements}

The authors acknowledge the financial support of the european project BIOTOBIO (Training and Mobility of Researchers) and grant no. BD/3242/94 awarded to Maria Olivia Pereira, and the financial support provided by Instituto de Biotecnologia e Química Fina (IBQF) and Fundação Luso-Americana para o Desenvolvimento (FLAD).

\section{References}

Burns, R.G. (1989). Microbial and enzyme activities in soil biofilms. Structure and Function of Biofilms, W. G. Characklis and A. Wilderer (Eds), Wiley-Interscience, pp. 333-349.

Burns, R.G. (1975). Factors affecting pesticide loss from soil. Soil Biochemistry, E.A. Paul and A.D. McLaren (Eds), Marcel Dekker, New York, pp. 103-141.

Nichols, W.W. (1989). Susceptibility of biofilms to toxic compounds. Structure and Function of Biofilms, W.G. Characklis and A. Wilderer (Eds), Wiley-Interscience pp. 321-331.

Nogueira, R., Lazarova, V. and Melo, L.F. (1998). Respirometric tests applied to the monitoring of a nitrifying biofilm reactor, International Speciality Conference "Microbial Ecology of Biofilms: Concepts, Tools, and Applications," Illinois, USA, 8-10 October.

Srinivasan, R., Stewart, P. S., Griebe, T., Chen, C-I. and Xu, X. (1995). Biofilm parameters influencing biocide efficacy. Biotechnol. and Bioeng. 46, 553-560.

Stotzky, G. (1986). Influence of soil mineral colloids on metabolic processes, growth, adhesion, and ecology of microbes and viruses. Interactions of Soil Minerals with Natural Organics and Microbes, P.M. Huang and M. Schnitzer (Eds) Soil Society of America, Inc., Wiscosin, pp. 305-427. 